\title{
The Effect of Grammatical Collocation Instruction on Understanding ESP Texts for Undergraduate Computer Engineering Students
}

\author{
Zeinab Abedi \\ Garmsar Branch, Islamic Azad University (IAU), Iran \\ Mohsen Mobaraki \\ Birjand univercity, Iran
}

\begin{abstract}
The researcher administered a Comprehensive English Language Test (CELT) to 80 learners and then according to their grades limited them to 60.The subjects were divided into two homogenous groups (30 subjects in control group and 30 subjects in experimental). Then a pretest was administered to both groups. The subjects who played the role of the control group kept pace with the teacher who taught the book named "English for Computer Science". It should be noted that this group were taught the mentioned book without instructing grammatical collocations (just through a curriculum book). The experimental group was taught the same book through instructing grammatical collocations. Both groups had instruction for sixty- minute periods for ten sessions. To be sure of the effect of the treatment, the researcher tested both groups by using a posttest. The scores on the result of pre and posttest showed the efficiency of the two methods. Finally, a T-test was conducted to examine the differences of the mean test scores of the two groups. The results of the pre and posttest showed a t-value greater than the t-critical. Therefore, the null hypothesis was rejected and we came to this conclusion that grammatical collocation instruction had significant effect on understanding ESP texts for undergraduate computer engineering students.
\end{abstract}

Index Terms - collocation, grammatical collocation, ESP

\section{INTRODUCTION}

We believe that for the study of languages for specific purposes has had a long and interesting history going back, some would say, as far as the Roman and Greek Empires. Since the 1960s, English for specific purposes (ESP) has become a vital and innovative activity within the teaching of English as a foreign or second language (TEFL/TESL) movement (Howatt, 1984, as cited in Dudley - Evans and ST Jhon, 1998). ESP emerged as an approach to teaching foreign students in courses other than General English (GE) in order to prepare the students to deal with the specific-purpose-written-texts and oral discourse that are of frequent and immediate use for the students of, e.g., Physics, computer engineering, etc. Some of its teaching, ESP has developed its own methodology, and its research clearly draws on research from various disciplines in addition to applied linguistics. This openness to the insights of other disciplines is a key distinguishing feature of ESP (as cited in as cited in Dudley - Evans and ST Jhon, 1998).

While linguists have pointed out the importance of recurrent word combinations or more specifically of collocations (Celce-Murcia \& Larsen-Freeman, 1983, pp.55-56; Benson, 1989), few investigate the effects of collocation instruction. Even when teachers deal with lexis in classes, they cover a limited aspect of lexis. It seems that teachers have only dealt with semantics of separate words, and have not sufficiently treated fixed expressions, collocations, and patterns which are considered to be of importance for acquiring language (Sinclair, 1991; Hunston, Francis and Manning, 1997, as cited in Kasuya,2000).). Regardless of their mother tongues, university students are often required to read textbooks in English, mainly because of the paucity of materials in their first language. These textbooks include numerous collocations and formulaic languages. Without sufficient collocation competence, university students would have difficulty studying ESP courses. Lewis' proposal of collocation instruction is supported by many language teaching experts, such as McCarthy \& O'Dell (2005), Nattinger \& DeCarrico (1992), Nesselhauf (2003), and Nation (2001). These scholars believe that learning collocations could expand vocabulary repertoire and enhance reading speed and fluency. What is more, sufficient collocation competence could help readers make accurate predictions and improve reading comprehension. Despite the theoretical support, few empirical studies investigate how to teach collocations and what effects collocation instruction would bring to the development of the students' reading proficiency.

\section{Definitions of Collocation}

Poulsen (1995, p.14) presents five definitions of 'collocation', which all have some form of co-occurrence as a central 
element:

(a) The tendency for lexical items to co-occur in a text, or in a text corpus, whether or not they form a syntactic pattern.

(b) The co-occurrence of lexical items in a syntactic pattern, only restricted by general selection restrictions (also referred to as 'free/open collocation').

(c) The tendency for lexical items to co-occur in a syntactic pattern restricted not only by general selection restrictions, but also by usage restrictions on one element (often referred to as 'restricted collocation').

(d) The co-occurrence of lexical items in an unexpected, creative way that conflicts with general selection restrictions and/or usage restrictions.

(e) The tendency for the lexical item to co-occur with a preposition or grammatical structure such as an infinitive or clause.

Lewis (1994) defines collocation as a subcategory of multi-word items, made up of individual words that habitually co-occur and can be found within the free-fixed collocational continuum. Celce-Murcia (1991) defines collocation as a co-occurrence of lexical items in combinations, which can differ in frequency or acceptability (as cited in Małgorzata Martyńska, 2004).

\section{A. A Note on the History of the Term 'Collocation'}

Collocation has been investigated using three major approaches. The oldest, the lexical approach, goes back to Firth (1951), who holds that meaning by collocation is an "abstraction at the syntagmatic level" and is not directly linked to the "conceptual or idea approach to the meaning of words" (p. 196). Later, this framework was adapted by Halliday (1966) and Sinclair (1991). Another approach, the semantic approach, transcends observation and tries to determine the specific shape collocations take, why words collocate with certain other words, and how the meaning of a word is reduced to its ultimate contrastive elements resulting in the atomization of meaning (Katz \& Fodor, 1963, p. 175, as cited in Shokouhi, 2010). In this approach, particular lexical areas can be identified in which each term helps to delimit its neighbors and is delimited by them (Ullmann, 1962, p. 30, as cited in Shokouhi, 2010). Semantic analysis adopts componential analysis on the basis of semantic opposition or dimensions of contrast. The third approach, which is the concern of this study, is a structural one. This approach takes collocation to be determined by its structural patterns. This grammatical perspective contrasts somewhat with the previous two approaches in that its concentration is chiefly grammatical and lexical (Gitsaki, 1996, p. 17, as cited in Shokouhi, 2010). Lexis cannot be separated from grammar, because the two are distinctive but related aspects of one phenomenon (Bahns, 1993, p. 57, as cited in Shokouhi, 2010). With respect to grammar and lexis, Kjellmer (1990), in establishing the extent to which an individual word class is collocational or non-collocational, shows that articles, prepositions, singular and mass nouns, as well as the base form of verbs are collocational in nature. In contrast, adjectives, singular proper nouns, and adverbs are not. Kjellmer then concludes that English words are scattered across a continuum that extends from those items whose contextual company is entirely predictable to those whose contextual company is completely unpredictable. Gitsaki (1996), by the analysis of a vast number of collocations, distinguished 37 categories of collocation overall: 8 lexical and 29 grammatical. Lewis and Hill (1997) reduced this number to five main categories: adjective/noun, verb/noun, noun/verb, adverb/adjective, and verb/adverb. (as cited in Shokouhi, 2010).

\section{B. Lexical Collocations}

Lexical collocations do not contain grammatical elements, but are combinations of nouns, adjectives, verbs, adverbs (Bahns, 1993). Benson has described lexical collocations as usually consisting of two equal lexical components. It consists of various combinations of content words; it does not contain prepositions, infinitives, and relative clauses.

\section{Grammatical Collocations}

Grammatical collocations consist of a noun, or an adjective or a verb, plus a particle (a preposition, an adverb or a grammatical structure such as an infinitive, a gerund, or clause) (Bahns, 1993:57, as cited in Shokouhi, 2010). The followings are the examples: at night, extend to, good at, fall for, to be afraid that. These examples are grammatical collocations which are lexicalized as single units whose meanings are formulaic and whose co-occurence are highly likely. They are sometimes idiomatic, because their meanings do not reflect the meanings of the elements, such as run out of (to reach an end of stock, supplies) or put up with (tolerate). However, there are similar grammatical combinations which do not have such a strong sense of belonging together.

\section{Types of Grammatical Collocations}

According to Benson, Benson and Ilson (1986), English grammatical collocations fall into the following combinations: noun+preposition, noun+to- infinitive, noun+that-clause, preposition + noun, adjective+ preposition, predicate adjective+ to-infinitive, adjective+ that-clause, and the English 19 verb patterns, (as cited in Małgorzata Martyńska, 2004).

\section{Noun + preposition combinations}

Not all noun + preposition combinations can be considered as collocations due to the highly predictable meaning of 
some prepositions, such as of and by. So, noun + of / by combinations are considered free combinations. The following phrases are examples of noun + preposition collocations: blockade against, apathy towards.

\section{Noun + to + infinitive}

There are five syntactic patterns in which noun + to + infinitive construction is most frequently encountered, (as cited in Moehkardi, R. R. D. 2002):

a. It was a pleasure (a problem, a struggle) to do it.

b. They had the foresight (instructions, an obligation, a permission) to do it.

c. They felt a compulsion (an impulse, a need) to do it

d. They made an attempt (an effort, a promise, and a vow) to do it.

e. He was a fool (a genius, an idiot) to do it.

\section{Noun + that-clause}

The noun + that-clause combinations that are considered collocational are those using subject pronouns,(as cited in Moehkardi,R. R. D. 2002): For example:

We reached an agreement that she would represent us in court.

He took an oath that he would do his duty.

However, when the 'that-clause' can be replaced by 'which-clause' as that in relative clauses, such a noun + that-clause construction is not considered as collocational. For example:

We reached into an agreement that/ which would go into effect in a month.

\section{Preposition + noun combinations}

Any combinations of preposition and noun can fall into this category, however, the choice of preposition with certain noun is not at random. For example: by accident, in advance, in agony, etc.

\section{Adjective + preposition combinations}

Some adjectives are followed by a prepositional phrase. The adjective+ preposition combination that is considered collocational is the one that occurs in the predicate (verbless clause). However, past participial adjective followed by preposition by is not considered collocational because this construction is regular and predictable. For example:

They are angry at the children,

They are hungry for news,

*The ship was abandoned (by its crew) is not considered collocational.

\section{Predicate adjective + to + infinitive}

These adjectives occur in two basic constructions with infinitives.

a. adjectives with dummy subject "it" such as it was necessary to work; also possible it was necessary for him to work (the insertion of prepositional phrase).

b. adjectives with real and animate subject, such as: She is ready to go; or with inanimate subject, such as: It (the bomb) is designed to explode at certain temperatures; or with either animate or inanimate subject: She was bound to find out or It (the accident) was bound to happen.

\section{Adjective + that clause}

Some adjectives can be followed by that- clause, for example:

She was afraid that she would fail her examination.

Several adjectives followed by present subjunctive in formal English are collocational, such as: It was imperative that we be there.

\section{Collocational verb patterns}

English verb patterns have 19 types, (as cited in Moehkardi,R. R. D. 2002) as follows:

a.Shift of an indirect object to a position before the direct object of transitive verbs is allowed, for example:

He sent the book to his brother-

He sent his brother the book

He sent the book to him - He sent him the book

If both objects are pronouns the common pattern is:

He sent it to him.

b. Shift of an indirect object to a position before the direct object by deleting to is not allowed, for example:

They described the book to her; but not * they described her the book.

Other common verbs that fit this category are mention, return, scream, etc.

c. Transitive verb with preposition for allows the deletion of for and the shift of the indirect object to a position before the direct object. For example:

She bought a shirt for her husband; also possible: She bought her

husband a shirt, or She bought a shirt for him, or She bought him a shirt.

d. The verb forms a collocation with a specific preposition and an object, for example:

They based their conclusions on the available facts

We adhered to the plan.

However, the following similar constructions are not collocations, but free combinations of verb + preposition 
denoting 'location' or 'means' or 'instrument'

We walked in the park

They came by train

e. Verbs are followed by infinitive, for example:

They began to speak

She continued to write.

However, verbs + to infinitive meaning "purpose" are not included as collocational combination, for example:

He was running (in order) to catch the bus.

She stopped (in order) to chat.

f. Verbs are followed by bare infinitive

These verbs, except dare, help, and need, are called modals. The verbal phrases had better and would rather also fit this pattern. For example:

They must work.

We had better go now.

g. Verbs are followed by second verb in - ing form, for example:

They kept talking.

We enjoyed watching television.

Some verbs in this category may be synonymous:

He began reading or He began to read are similar in meaning.

And some other verbs of this category may have different construction and meaning, for example:

He remembered telling him the story and He remembered to tell him the story are different in meaning.

h. Transitive verbs are followed by an object and to + infinitive, for example:

They asked the students to participate in discussion.

They permitted the children to watch television.

Many of the verbs in this pattern can be followed by infinitive to be, for example, she asked me to be punctual. Furthermore, most of the verbs in this construction can be passivized.

i. Transitive verbs are followed by a direct object and an infinitive without to.

Most I-pattern verbs cannot be passivized, for example:

We let them use the car.

We saw them leave the house.

j. Verbs are followed by an object and a verb in -ing form, for example:

I caught him smoking in his bedroom.

We found the children sleeping on the floor.

Some verbs in this category (especially verbs of perception, like see, hear, feel) may have similar constructions with that of construction in I-pattern. We saw him smoke the cigarette beside We saw him smoking. J-pattern verbs usually can be passivized.

k. Verbs can be followed by a noun or pronoun and gerund, for example:

This fact justifies Bill's coming late.

They love his clowning.

I cannot imagine their stealing apples.

Please excuse my waking you so early.

However, possessive constructions are often considered awkward, more common expressions for the same meaning will use the following alternative:

I cannot imagine them stealing apples.

This fact justifies Bill for coming late.

Please excuse me for waking you so early.

l. Verbs are followed by a noun clause beginning with conjunction that, for example:

They admitted that they were wrong.

We hoped that the weather would be nice.

Some verbs always take an object noun or pronoun before that-clause, for example:

She assured me that she would arrive on time.

They convinced us that we should invest our money.

Some verbs in this category allow the insertion of the fact.

For example:

He acknowledged (admitted/confirmed/ etc) the fact that he was guilty.

m. Transitive verb can be followed by a direct object, an infinitive to be and adjective / past participle/ noun/pronoun, for example:

We considered her to be very capable / well-trained / a competent engineer.

n. Transitive verbs are followed by a direct object and adjective/ past participle or noun/pronoun, for example: 


\section{She dyed her hair red.}

He found them interesting.

Some verbs in this category may also be used with M-verb pattern, for example:

We considered her very capable.

o. Transitive verbs are followed by two objects, for example:

The teacher asked the students questions.

The police fined them fifty pounds.

p. Intransitive /reflexive / transitive verbs must be followed by an adverbial (an adverb/a prepositional phrase/a noun phrase/a clause), for example:

He carried himself with dignity; but not * He carried himself.

The meeting will last two hours; but not *The meeting will last.

Other verbs in this category are: come, sneak, weigh, etc. However some of these verbs may have senses that do not require an adverbial, for example: They are coming, in addition to They are coming home.

q. Verb can be followed by an interrogative word, such as how, what, when, etc, for example:

He always wants what I want.

She knows when to keep quiet.

However, some verbs in this construction need an object, such as:

They told us what to do.

She asked me why she had come.

r. Dummy 'it' is followed by transitive verbs (often expressing emotions), infinitive, that + clause, or by either, for example:

It puzzled me that he never answered the telephones. It surprised me to learn of her decision.

S. SVC (adjective or noun)

Here some transitive verbs are followed by a predicate noun or a predicate adjective.

She became an engineer.

She looks fine.

\section{DEFINITIONS OF ESP}

Hutchinson and Waters (1987) see ESP as an approach rather than a product, by which they mean that ESP does not involve a particular kind of language, teaching material or methodology. They suggest that ESP is based on this simple question: Why does a learner need to learn a foreign language? The answer to this question relates to the learners, the language required, and the learning context; and thus establishes the primacy of need in ESP. Need is defined as the reasons for which the student is learning English, which will vary from study purposes such as following a postgraduate course in an English speaking country to work purposes such as participating in business meetings or taking hotel bookings. These purposes are the starting points which determine the language to be taught.

Strevens' (1988) definition of ESP makes a distinction between four absolute characteristics and two variable characteristics. The absolute characteristics are that ESP consists of English language teaching which is:

designed to meet specified needs of the learner;

- related in content (that is in its themes and topics) to particular disciplines, occupations, and activities;

- centred on language appropriate to those activities in syntax, lexis, discourse, semantics, and so on, as well as in analysis of the discourse;

- may not be taught according to any pre-ordained methodology.

The variable characteristics are that ESP

- may be restricted to the learning skills to be learned (for example reading only);

- not taught according to any pre-ordained methodology.

Robinson (1991) also accepts the primacy of needs analysis in defining ESP. Her definition is based on two key defining criteria and a number of characteristics that are generally found to be true of ESP. Her key criteria are that ESP is normally goal-directed, and that ESP courses develop from a needs analysis, which aims to specify as closely as possible what exactly it is that students have to do through the medium of English (Robinson, 1991:3, as cited in Dudley - Evans and ST Jhon, 1998).

\section{A. The Origins of ESP}

As with most developments in human activity, ESP was not a planned and coherent movement, but rather a phenomenon that grew out of a number of converging trends. These trends have operated in a variety of ways around the world, but we can identify three main reasons common to the emergence of all ESP, (as cited in Hutchinson and Waters, 1987).

1. The demands of a brave new world

The end of the Second World War in 1945 heralded an age of enormous and unprecedented expansion in scientific, 
technical, and economic activity on an international scale. This expansion created a world unified and dominated by two forces- technology and commerce- which in their relentless progress soon generated a demand for an international language. For various reasons, most notably the economic power of the United States in the post-war world, this role fell to English (as cited in Hutchinson and Waters, 1987).

2. A revolution in linguistics

At the same time as the demand was growing for English courses tailored to specific needs, influential new ideas began to emerge in the study of language. Traditionally the aim of linguistics had been to describe the rules of English usage, that is, the grammar. However, the new studies shifted attention away from defining the formal features of language usage to discovering the ways in which language is actually used in real communication (Widdowson, 1978, as cited in Hutchinson and Waters, 1987).

3. Focus on the learner

New developments in educational psychology also contributed to the rise of ESP, by emphasizing the central importance of the learners and their attitudes to learning (e.g. Rodgers, 1969). Learners were seen to have different needs and interests, which would have an important influence on their motivation to learn and, therefore, on the effectiveness of their learning. This lent support to the development of courses in which 'relevance' to the learners' needs and interests was paramount,( as cited in Hutchinson and Waters, 1987).

\section{B. Classification of ESP}

In this section we introduce and explain the many abbreviations that have been used in describing ESP, terms such as English for academic purposes (EAP), English for occupational purposes (EOP), English for science and technology (EST) and English for business purposes (EBP), (Dudley-Evans and St John). ESP has traditionally been divided into two main areas: English for Academic Purposes (EAP) and English for Occupational Purposes (EOP). The classification is generally presented in a tree diagram as in Figure 1. (taken from Robinson, 1991:3-4, as cited in Dudley - Evans and ST Jhon, 1998).

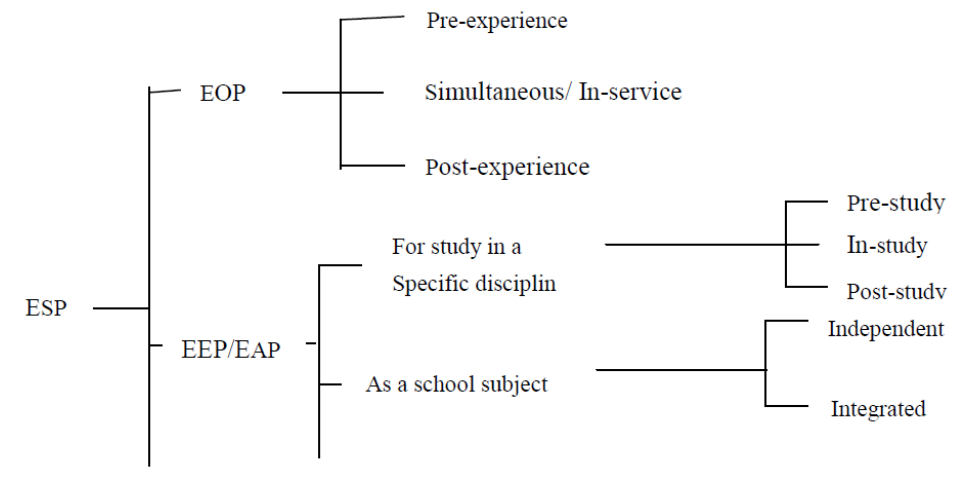

The diagram has, as well as the division into EAP and EOP, a useful division of courses according to when they take place. These distinctions are very important as they will affect the degree of specificity that is appropriate to the course. A pre-experience or pre-study course will probably rule out any specific work related to the actual discipline or work as students will not yet have the required familiarity with the content, while courses that run parallel to follow the course of study in the educational institution or workplace will provide the opportunity for specific or integrated work. Another typical tree diagram for ESP, which divides EAP and EOP according to discipline or professional area, is shown in figure 2,( , as cited in Dudley - Evans and ST Jhon, 1998).

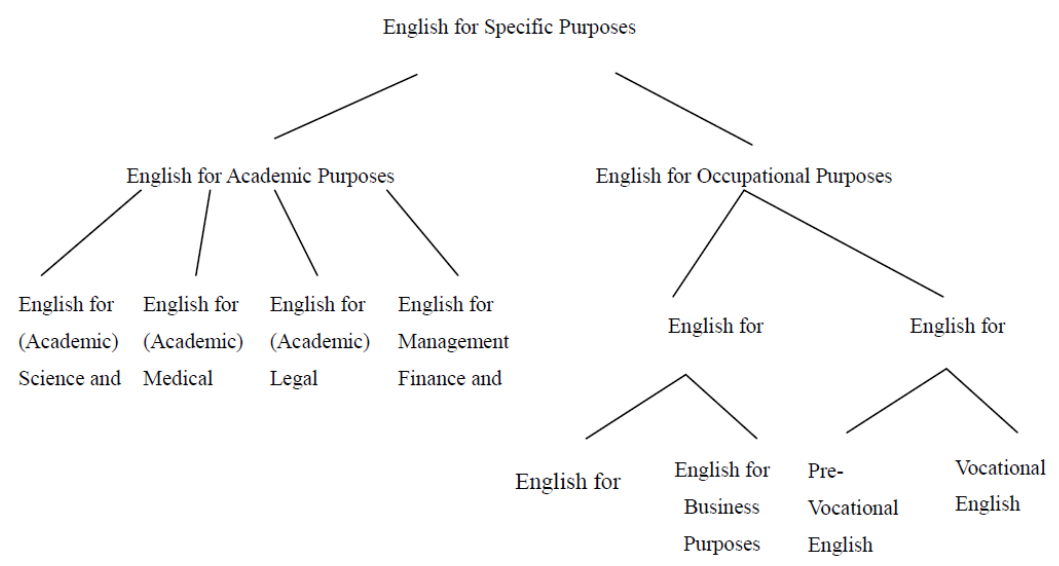


In EAP, EST has been the main area, but English for Medical Purposes (EMP) and English for legal purposes (ELP) have always had their places. Recently, the academic study of business, finance, banking, economics and accounting has become increasingly important, especially on Masters in Business Administration (MBA) courses, but, as yet, no specific acronym has been established for such courses.

The term EOP refers to English that is not for academic purposes; it includes professional purposes in administration, medicine, law and business, and vocational purposes for non-professionals in work or pre-work situations, (as cited in Dudley - Evans and ST Jhon, 1998). Thus, there is a distinction between studying the language and discourse of, for example, medicine for academic purposes, which is designed for medical students, and studying for occupational (professional) purposes, which is designed for practicing doctors.

This classification places English for Business purposes (EBP) as a category within EOP. EBP is sometimes seen as separate from EOP as it involves a lot of General English as well as specific purpose English, and also because it is such a large and important category. A business purpose is, however, an occupational purpose, so it is logical to see it as part of EOP.

Within English for Vocational Purposes (EVP) there are two subsections: Vocational English, which is concerned with the language of training for specific trades or occupations, and Pre-Vocational English, which is concerned with finding a job and interview skills. It also deals with succeeding in a job through an understanding of employer expectations and policies (Anne Lomperis, personal communication, as cited in Dudley - Evans and ST Jhon, 1998).

A distinction should also be made between common-core English for General Academic Purposes (EGAP) and English for specific Academic Purposes (ESAP) (Blue, 1988a). An awareness of the distinction between EGAP and ESAP is crucial to a full understanding of EAP (Blue, 1988a). EGAP refers to the teaching of the skills and language that are common to all disciplines; ESAP refers to the teaching of the features that distinguish one discipline from others, (as cited in, as cited in Dudley - Evans and ST Jhon, 1998, page.41).

English for General Academic Purposes isolates the skills associated with study activities such as listening to lectures; participating in supervisions, seminars, and tutorials; carrying out practicals (largely in science or engineering courses); reading textbooks, articles and other reading material; and writing essays, examinations answers, dissertations and reports (Blue, 1993). There are particular skills associated with each of these, so that, to take one example, reading almost any textbook involves understanding the main ideas, distinguishing the main ideas and the supporting detail, making notes on the main ideas, evaluating the writer's point of view, and, where necessary, skimming to understand the gist of the argument or scanning to find specific information. The detailed focus on reading skills, such as establishing main points or inferring meaning from context that form a major part of EAP courses, can just as validly be taught as part of an intermediate to advanced General English course,(as cited in Dudley - Evans and ST Jhon, 1998, page.41).

English for Specific Academic purposes integrates the skills work of EGAP with help for students in their actual subject tasks. It adopts a developmental role (Turner, 1996) by showing how students can transfer the skills they have learnt in the EGAP classes to the understanding of their actual lectures or reading texts. This kind of work generally involves some cooperation with the actual subject department. Such contacts with the department and the possibilities for research into disciplinary communication often raise the status of the EAP lectures in the eyes of subject departments, (as cited in Dudley - Evans and ST Jhon, 1998, page.41).

\section{Statement of The Problem}

With changing view in teaching vocabulary, the concept of collocation has recently become a research focus in second language learning. Lewis (1997) argued that the real definition of a word is a combination of its referential meaning and its collocation field (p.97). Bahns (1993) further reported the notion of collocation as a negatively ignored element in regular syllabus design, which resulted in learners' deficiency of collocation knowledge. Collocations are rarely learned and experienced, and most of the times ignored in language classes in Iran. The startling fact here is that just a low percentage of learners will ever pay attention to collocations. The results whatsoever, whether young teachers are not aware of collocation important role or the students unconsciously ignore learning them, lead to incomplete English learning, (as cited by Fahim, Motallebzadeh, and Sazegar, 2011).

Therefore, collocations should be focused in classroom teaching and teachers must earnestly raise awareness of collocations among students. EFL or ESL teachers should make students aware of collocations and encourage them to store collocations in their memory. They should help learners notice collocations (as cited in Karoly, 2005). The aim of the current study is to examine the effect of teaching grammatical collocations on understanding ESP texts for undergraduate computer engineering students in Iran; it also aims to investigate the effect of explicit grammatical collocation teaching on the development of reading proficiency of computer engineering students. Collocation errors can be traced to the neglect of conscious teaching of collocations in L2 classrooms.

\section{SignifiCANCE AND JUSTIFICATION OF THE StUdy}

In ESP contexts, language of the selected texts to be worked on is very professional. Therefore a great care should be taken in order to create an interaction with such texts. Students as potential agents of change and political and 
ideological beings may become aware of power of language through reciprocal understanding and mutual transformation of worlds behind words (Freire, 1972). ESP, due to its multi-disciplinary nature, has got great significance in our educational setting where English is foreign language and students need it for their academic or professional trends. Scholars (Hutchinson 1987, Dudley 1998, widdowson 1978) worked a lot on how to see language in ESP classes and focused on language description, learning theories, and needs analysis in these contexts. But it's very crucial how to analyze these issues to make students aware of the way they convey their ideas in foreign language.

An understanding of collocation is imperative for all learners, and for those on advanced level courses, it is essential that they are not only aware of the variety of this feature of the language but that they actively acquire more and more collocations both within and outside the formal teaching situation (as cited in Nesselhauf, 2003). Taking the aforementioned issues in consideration, this study aims at answering the following research questions.

\section{RESEARCH QUESTION:}

Does teaching grammatical collocation have any effect on understanding ESP texts for undergraduate computer engineering students?

\section{RESEARCH HYPOTHESIS}

To obtain logical answer to research question the following null hypothesis was formulated:

"Teaching grammatical collocation has no effect on understanding ESP texts for undergraduate computer engineering students".

\section{METHOD}

\section{A. Participants}

Participants involved in the study are 80 (both sexes) sophomore Iranian students majoring at computer engineering at Islamic Azad university of AzadShahr. All the students included in the study are between 18-25 years old. They are both female and male with diverse social background; it has been assumed that those variables do not have any impact on this study.

At first, a Comprehensive English Language Test (CELT) is given to all subjects to determine their English language proficiency level. This being the case, 20 students who have extreme scores, were not qualified to be included in this study. They have, therefore, been excluded. All in all, a total of 20 students were excluded from the study reducing the number of subjects to 60 .

\section{B. Instrumentation}

In order to gather the data needed to test the hypothesis of this research, two sets of tests were used:

1. A Comprehensive English Language Test (CELT) was administered to 80 students. This is a standardized test which is used to evaluate the English proficiency of those whose native language is not English. It is a test of grammar, vocabulary and reading comprehension.

2. A teacher-made grammatical collocation test was administered as both pretest and posttest (Appendix C). It consisted of 40 multiple choice questions. In this section the reliability (Cronbakh's Alpha) is calculated for grammatical collocation test. The result shows that Alpha is .620 and it can be acceptable. Since this number is large enough and it is near to one, the grammatical collocation test is reliable. As for the validity of this test, content validity was the best criterion. Therefore, the grammatical collocation test was checked by some experts in the field of TEFL (the supervisor and some MA graduates in TEFL). At last, 40 multiple choice questions were chosen out of 58.

TABLE 1.

RELIABILITY OF TEACHER-MADE GRAMMATICAL COLLOCATION TEST

\begin{tabular}{|l|l|}
\multicolumn{2}{c}{ RELIABILITY STATISTICS } \\
\hline Cronbakh's Alpha & N of Items \\
\hline .620 & 40 \\
\hline
\end{tabular}

\section{Procedure}

At the initial stage, students in the experimental group were introduced to the concept of grammatical collocation by providing some exercises to be completed as class work to raise their awareness of grammatical collocations.

The experimental group received explicit and systematic grammatical collocation instruction. Explicit information is learnt consciously. 9 ESP texts are selected to teach the participants the grammatical collocations throughout 8 weeks. Explanation was provided in students' mother tongue. The focus was mainly on grammatical collocations, because the comprehension of grammatical collocations is said to be more difficult than that of lexical collocations. Cobb (2000) claims that all collocations are of an arbitrary nature and there is no logic underlying them. He maintains that this arbitrariness, which is more noticeable in the case of grammatical collocations, certainly creates problem for those who 
are not native speakers of English. A further source of difficulty is the unfamiliarity of subjects with English collocations due to insufficient exposure. Tajalli (1994) maintains that exposure or lack of exposure to a certain type of collocation influences the learning of that kind of collocation, (as cited in Shokouhi, 2010).

But the procedure in the control group was characterized by absence of any sort of explicit teaching of grammatical collocations.

\section{Design}

The current study adopts the intact group design. The reason for choosing this design rested upon the fact that it was impossible for the researcher to assign the students randomly to the language classes.

\section{E. Data Analysis}

In order to test the hypothesis in this study, there would be a T-test, which is a quantitative procedure for determining the statistical significance of the difference between means on two sets of scores. According to Hatch and Farhadi (1981 p.119), the T-test is an excellent statistical procedure to use in comparing two means. All researchers should keep the following cautions in mind: a) Each $\mathrm{S}$ must be assigned to one (and only one) group in the experiment if you wish to use the regular t-test formula. b) The scores on the independent variable should be measured on an interval scale. c) You must not do multiple t-tests, comparing mean 1 with mean 2 and mean 1 with mean 3 and mean 2 with mean 3 , etc. If you wish to make cross-companies, you must use the ANOVA (analysis of variance) procedure. d) The variances of scores in the population are assumed to be equal and scores are assumed to be normally distributed.

\section{F. Result Concerning the Pretest}

An independent t-test was run to compare the experimental and control groups' mean scores on the pre-test before conducting the study. The t-observed value was -.14 .

TABLE 2.

INDEPENDENT SAMPLES TEST

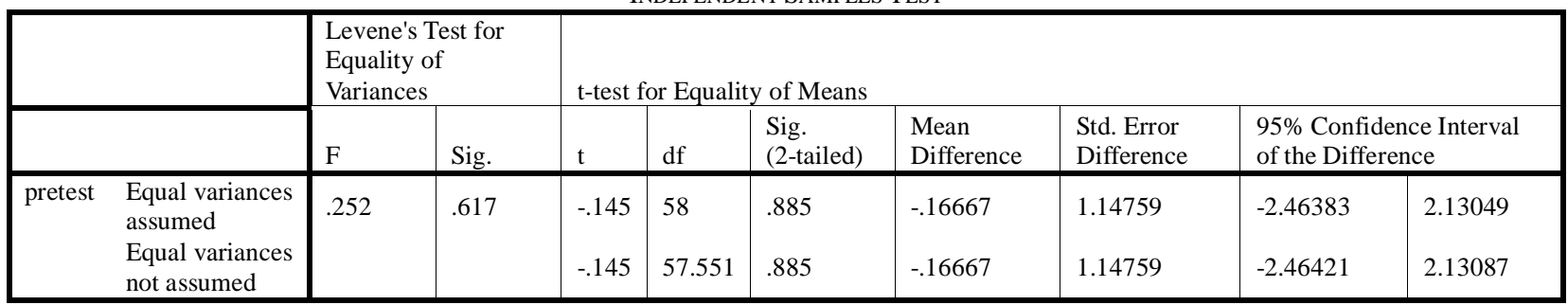

Since the t-observed value of -.14 did not exceed its critical value it can be claimed that prior to the treatment, there is not any noticeable difference between the two groups' mean scores of grammatical collocation.

The descriptive statistics displayed in Table 3. indicate that the mean scores for the experimental and control groups are 14.53 and 14.70 .

TABLE 3.

PRETEST: CONTROL GROUP AND THE EXPERIMENTAL GROUP

\begin{tabular}{|l|l|l|l|l|}
\hline Groups & N & Mean & Std. Deviation & Std. Error mean \\
\hline Experimental & 30 & 14.5333 & 4.63669 & .84654 \\
Control & 30 & 14.7000 & 4.24386 & .77482 \\
\hline
\end{tabular}

Based on these results it can be concluded that the experimental and control groups were homogenous in terms of their ability on grammatical collocation.

\section{G. Result Concerning the Post-test}

After the treatment, An independent t-test was done to compare the two groups' mean scores to probe the effect of grammatical collocation instruction on understanding ESP texts. The t-observed value was 6.76 (table 4). This amount of $\mathrm{t}$-value was higher than the critical value of 2 at 58 degrees of freedom. 
TABLE 4.

INDEPENDENT SAMPLES TEST

\begin{tabular}{|c|c|c|c|c|c|c|c|c|c|c|}
\hline & & \multicolumn{2}{|c|}{$\begin{array}{l}\text { Levene's Test for Equality } \\
\text { of Variances }\end{array}$} & \multicolumn{7}{|c|}{ t-test for Equality of Means } \\
\hline & & $\mathrm{F}$ & Sig. & $\mathrm{t}$ & $\mathrm{df}$ & $\begin{array}{l}\text { Sig. } \\
\text { (2-tailed) }\end{array}$ & $\begin{array}{l}\text { Mean } \\
\text { Difference }\end{array}$ & $\begin{array}{l}\text { Std. Error } \\
\text { Difference }\end{array}$ & $\begin{array}{l}95 \% \text { Con } \\
\text { of the Dif }\end{array}$ & $\begin{array}{l}\text { ence Interval } \\
\text { ence }\end{array}$ \\
\hline posttest & $\begin{array}{l}\text { Equal variances } \\
\text { assumed } \\
\text { Equal variances } \\
\text { not assumed }\end{array}$ & 8.384 & .005 & $\begin{array}{l}6.766 \\
6.766\end{array}$ & $\begin{array}{l}58 \\
46.755\end{array}$ & $\begin{array}{l}.000 \\
.000\end{array}$ & $\begin{array}{l}10.56667 \\
10.56667\end{array}$ & $\begin{array}{l}1.56177 \\
1.56177\end{array}$ & $\begin{array}{l}7.44045 \\
7.42436\end{array}$ & $\begin{array}{l}13.69288 \\
13.70897\end{array}$ \\
\hline
\end{tabular}

Since the t-observed value of 6.76 was more extreme than its critical value it can be claimed that there was a noticeable difference between the two groups' mean scores on the post-test of grammatical collocation.

TABLE 5.

GROUP STATISTICS

\begin{tabular}{|ll|l|l|l|l|}
\hline & & $\mathrm{N}$ & Mean & Std. Deviation & Std. Error Mean \\
\hline \multirow{2}{*}{ posttest } & Experimental group & 30 & 26.2333 & 7.38444 & 1.34821 \\
& Control group & 30 & 15.6667 & 4.31783 & .78832 \\
\hline
\end{tabular}

\section{H. Result Concerning the Hypothesis of the Study}

As displayed in table 5. The descriptive statistics indicated that the mean scores for the experimental and control groups on the grammatical collocation were 26.23 and 15.66 .

The $\mathrm{t}$ - test also showed that the mean difference of two groups was significant. The significance was 000 , and $\mathrm{P}=$ $000<0.05$.

Since the t-observed value of 6.76 was more extreme than its critical value it can be claimed that after the treatment, there was a noticeable difference between the experimental and control groups' mean scores of the grammatical collocation. Accordingly, we can reject the Null-hypothesis at the 0.05 level of significance .That is to say; grammatical collocation instruction increased the mean score of the experimental group significantly.

\section{CONCLUSION}

It is confirmed that the application of the treatment has been effective because the results showed that the experimental group outperformed the control group. Mean scores of the control and experimental groups on the posttest indicated that language learners' mean score in the experimental group was significantly higher than language learners' mean score in the control group. This means that grammatical collocation instruction was effective in understanding ESP texts for undergraduate computer engineering students.

\section{REFERENCES}

[1] Anderson, R.C. \& Nagy, W.E. (1991). Word meanings. In R. Batt (Ed.), Handbook of reading research (pp. 690-724). New York, NY: Lomgman.

[2] Bahns, J. (1993). Lexical collocations: a contrastive view. ELT Journal, 47, 56-63.

[3] Bahns, J. \& Eldaw, M. (1993). Should we teach collocations?. System, 21: 101-114.

[4] Benson, M. (1989). "The Structure of the collocational Dictionary", in International Journal of Lexicograghy, Vol. 2 No.1, Oxford University Press.

[5] Benson, M., Benson, E. \& Ilson, R. (1986). The BBI Combinatory Dictionary of English, John Benjamins publishing Company.

[6] Blue, G. (1988a). Individualizing academic writing tuition. In P. Robinson (Ed.) Academic Writing: Process and product. ELT Documents 129.

[7] Blue, G. (1993). Language, Learning and Success: Studying through English. Developments in ELT. London: Macmillan, Modern English Teacher and the British Council.

[8] Celce-Murcia, M. (Ed.). (1991). Teaching English as a Second or Foreign Language. Second Edition. New York: Newbury House

[9] Celce-Murcia, M. and Larsen-Freeman, D. (1983). The Grammar Book: an ESL/EFL Teacher's Course. Cambridge: Newbury House

[10] Cobb, E. (2000). Testing EFL vocabulary. Oxford, UK: Pergamon Press.

[11] Dudley-Evans, T. (2000). Genre Analysis: a key to a theory of ESP. London: Modern English publications in Association with British Council.

[12] Dudley-Evans, T. \& Jo ST John, M. (1998). Developments in English for specific purposes. published by the press syndicate of the university of Cambridge, Cambridge, United Kingdom ,chapter one \& six(pp.95-101).

[13] Fahim, M., Motallebzadeh,Kh. and Sazegar,Z. (2011). The Effect of E-mailing on Vocabulary Retention of Iranian Lower Intermediate EFL Learners, Journal of Language Teaching and Research.

[14] Firth, J.R. (1951). Modes of meaning. In J. R. Firth (Ed.), papers in linguistics (pp. 115-197). Oxford, UK: Oxford University Press. 
[15] Francis, G., Manning, E., \& Hunston, S., (1997). Collins COBUILD verbs: patterns and practice. London: Harper Collins.

[16] Freire,p. (1972). Cultural action for freedom Penguin education. Harmondsworth: Penguin.

[17] Gitsaki, C. (1996). The development of ESL collocational Knowledge. A thesis submitted for PhD in the Center for Language Teaching and Research at the University of Queensland.

[18] Halliday, M. A. K. (1966). Lexis as a linguistic level. In C.E. Bazell, J. C. Catford.

[19] Hatch, E. \& Farhadi, H. (1981). Research design and Statistics for Applied Linguistics (p.119). University of California, Los Angeles.

[20] Howatt, A. P. R. 1984. A History of English language teaching. Oxford: University press.

[21] Hutchinson, T. (1987). 'What's underneath? - An interactive view of Materials Evaluation' in ELT Documents 126: Textbook and materials Evaluation, Pergamon.

[22] Karoly, Adrienn. (2005). The importance of raising collocational awareness in the vocabulary development of intermediate level learners of English.

[23] Kasuya, M.( 2000). Focusing on Lexis in English Classrooms in Japan: Analyses of Textbook Exercises and Proposals for Consciousness-raising Activities.

[24] Katz, J. and Fodor, J. (1963). The structure of semantic theory. Linguistics, 39, 170-175.

[25] Kjellmer, G. (1990). Patterns of collocability. In J. Aarts \& I.W. Meijis (Eds.), Theory and practice in corpus Linguistics (pp. 152-174). Amsterdam, The Netherlands: Rodopi.

[26] Lewis, M. (1994). The Lexical Approach. The State of ELT And A Way Forward. Hove: Language Teaching Publications.

[27] Lewis, M. \& Hill, J. (1997). A dictionary of selected collocations. Hove, UK: Language Teaching Publications.

[28] Martyńska, M. (2004). Do English language learners know collocations? , Institute of Linguistics, Adam Mickiewicz University.

[29] McCarthy, M. \& O'Dell, F. (2005). English collocation in Use. Cambridge: Cambridge University Press.

[30] Moehkardi,R. R. D. (2002). Grammatical and lexical English collocations: some possible problems to Indonesian learners of English.

[31] Nation, I. S. P. (2001). Learning vocabulary in another language. Cambridge: Cambridge University Press.

[32] Nattinger, J. R. \& DeCarrico, J.S. (1992). Lexical phrases and language teaching. Oxford: Oxford University Press.

[33] Nesselhauf, N. (2003). The use of collocations by advanced learners of English and some implications for teaching. Applied linguistics 24(2), 223-242.

[34] Poulsen,S. (1995). Collocations as a language resource, A functional and cognitive study in English phraseology. Ph.d. dissertation Institute of Language and Communication, University of Southern Denmark.

[35] Robinson, P. (1980). Definition of ESP. New York: prentice Hall.

[36] Robinson, P. (1991). ESP Today: a practitioner's Guide. Hemel Hempstead: Prentice Hall International.

[37] Rodgers, C. (1969). Freedom to learn, Merrill.

[38] Shokouhi, H. (2010). Collocational knowledge versus general linguistic knowledge among Iranian EFL learners. Shahid Chamran University, Iran.

[39] Sinclair, J. M. (1991). Corpus, concordance, collocation. Oxford, UK: Oxford University Press.

[40] Strevens, P. 1988. ESP after twenty years: a re-appraisal. In M. Tickoo (Ed.) ESP: State of the Art. Singapore: SEAMEO Regional Language Center.

[41] Tajalli, G. (1994). Translatability of English and Persian collocations. Paper presented at the second conference on translation. Tabrize University, Tabriz.

[42] Hutchinson,T. and Waters, A. (1987). A learning-centered approach. English foe specific purposes, Cambridge University press.

[43] Turner, j. (1996). Between the discourse of language and the language of discourses: The contested space of EAP. Paper given at the knowledge and Discourse Conference, Hong Kong.

[44] Ullmann, S. (1962). Semantics: An introduction to the science of meaning. Oxford, UK: Basil Blackwell Publishers.

[45] Widdowson, H. G. (1978). Teaching Language as Communication. Oxford: Oxford University Press.

Zeinab Abedi has recently completed an M.A. in Teaching English, i.e. TEFL/TESL on the subject of grammatical collocation instruction, University of Garmsar, Islamic Azad University (IAU), Iran. She is currently teaching at different English institutes and universities of Gonbad, Iran.

Mohsen Mobaraki is a PhD in Applied linguistics (child L2 acquisition) from Durham University, UK. He has got his BA and MA. from Allameh Tabatabaei University, Iran. He is currently working as an assistant professor of English in the department of Translation Studies and Linguistics at University of Birjand, Iran. His interests include teaching English as a second language, translation evaluation, sociology of translation, and Interpreting Studies. His published works are:

Mobaraki, M. (2011). Interpretation. Tehran: Rahnama Publication.

Mobaraki, M. (2011). Journalism and Newspapers. Tehran: Rahnama Publication. 